\title{
DEVELOPMENT AND ESTABLISHMENT OF COMPETITION
}

Постановка проблеми. Проблема конкурентоспроможності стосується всіх сторін життя суспільства. В умовах кризи підвищується рівень ризику діяльності суб'єктів господарювання та виникає додаткова необхідність у пристосуванні до мінливих ринкових умов. Тому питання розкриття сутності поняття «конкуренція» за часів економістів-класиків та дослідження ключових етапів становлення даної категорії сьогодні є важливим та актуальним.

Аналіз останніх досліджень і публікацій. Існування сучасного суспільства неможливе без рушійної сили, яка змушує людство рухатись вперед. Такою силою протягом усього шляху, що пройшло людство, виступає конкуренція. Дослідження питання шляхів розвитку та трактування дефрініцій конкуренції та конкурентоспроможності розкривається у працях вчених-економістів: Дж. Кейнса, А. Маршала, П. Самуельсона, А. Смітта, Дж. Стіглера, Е. Чеберлена, Ф. Енгельса, К. Маркса, М. Портера, Й. Шумпетера та інших. До вітчизняних науковців, які розглядали питання конкуренції та конкурентоспроможності, необхідно віднести Б. Базилевича, С. Мочерного, А. Гальчинського та багатьох інших. Разом із тим, у світовій практиці не існує єдиної точки зору у висвітленні вищезазначених дефініцій, що зумовлює необхідність подальших досліджень.

Постановка завдання. Мета статті - аналіз та узагальнення поглядів вчених щодо трактування понять «конкуренція», «конкурентоспроможність» на основі їх історичного генезису та фрормування відповідних концепцій.

Виклад основного матеріалу дослідження. Конкуренція $€$ важливим аспектом будь-якої ринкової системи господарювання. Необхідність якісної оцінки рівня конкурентоспроможності зумовлює потребу уміння вірно оцінити товар відносно конкурентів. Отже, виживання та успіх у такі неспокійні часи все більше залежать від конкурентоспроможності - здатності змагатися.

Звернувшись до історичних джерел, ми можемо досліджувати поняття конкурентоспроможності, з'ясувати сутність конкуренції, адже через призму конкуренції ми зрозуміємо суть конкурентоспроможності.

Дослідженням конкуренції займались багато вчених з різних країнах світу в різні часи. Кожен період був характерний своїми особливостями. Одним із перших науковців, які почали цікавитись природою даного явища, був А. Сміт.

Центральне місце в методології дослідження А. Сміта займає концепція економічного лібералізму, в основу якої, як і фізіократи, він поклав ідею природного порядку, тобто ринкових економічних відносин. У розумінні А. Сміта ринкові закони кращим чином можуть впливати на економіку, коли приватний інтерес стоїть вище суспільного, тобто коли інтереси суспільства в цілому розглядаються як сума інтересів складових його осіб. У розвиток цієї ідеї автор праці «Багатства народів» вводить поняття, які стали потім знаменитими, «економічна людина» і «невидима рука» [16].

* Науковий керівник: Місюк М.В. - д-р екон. наук, проф. 
«Невидима рука» незалежно від волі і намірів індивідуума - «економічної людини» - направляє її і всіх людей до найкращих результатів, вигоди і до більш високих цілей суспільства, виправдовуючи як би тим самим прагнення людини-егоїста ставити особистий інтерес вище суспільного [16].

Дану теорію підтримав та продовжив розвивати Д. Рікардо в своїй праці «Принципи політичної економії та оподаткування». Він побудував теоретичну модель досконалої конкуренції. Основна увага була сконцентрована на тому, як дана система функціонує в довгостроковій перспективі. Такий підхід дозволив відійти від деталей, пов'язаних 3 державним регулюванням, монопольною владою, географічними особливостями ринку і т.д., які в довгостроковій перспективі не мають вирішального значення. Для умов, які розглянув Д. Рікардо, принциповим є те, що ціни складаються під впливом попиту та пропозиції в результаті конкурентної боротьби. Таким чином, ним були обґрунтовані довгострокові варіанти вирішення проблеми зростання в умовах досконалої конкуренції, сорормульовані теорії цінності і розподілу на основі граничної продуктивності [10].

Проте іншого погляд дотримувався К. Маркс. У своїй праці «Капітал» він писав, що конкуренція, перш за все, в одній сфері виробництва здійснює встановлення однакової ринкової вартості і ринкової ціни з різних індивідуальних вартостей товарів. Але тільки конкуренція капіталів в різних галузях виробництва створює ціну виробництва, яка вирівнює норми прибутку різних галузей. Для утворення цін виробництва необхідно встановити більш високий розвиток капіталістичного способу виробництва, ніж для встановлення однакової ринкової вартості і ринкової ціни [5].

А. Маршалл, англійський економіст, лідер неокласичного напряму в економічній науці, дав визначення «досконалої конкуренції»: досконала конкуренція - ситуація на ринку, за якої існує велика кількість продавців (покупців) і кожен продає (купує) визначену й обмежену, тобто таку, що не забезпечує йому «вирішального голосу», частину однорідного продукту. Конкуренція $є$ досконалою тільки тоді, коли входження в галузь є вільним [6].

Продовжуючи досліджувати питання конкуренції, зустрічаємо не менш важливу думку П'єра Срафрфа, який вважає, що термін «конкуренція» $є$ більшою мірою ближчим до теоретичної моделі монополії, ніж до моделі досконалої конкуренції [27].

У Законі України «Про захист економічної конкуренції» економічна конкуренція (конкуренція) трактується як змагання між суб'єктами господарювання з метою здобуття завдяки власним досягненням переваг над іншими суб'єктами господарювання, внаслідок чого споживачі, суб'єкти господарювання мають можливість вибирати між кількома продавцями, покупцями, а окремий суб'єкт господарювання не може визначати умови обороту товарів на ринку [9]. У кембриджському словнику визначено, що конкуренція - ситуація, в якій люди або підприємства намагаються бути більш успішними один за одного. Наприклад, роблячи більше продажів на ринку [21].

Також потрібно пам'ятати про вплив на конкуренцію таких фракторів: рівень якості, репутація фрірми, роль реклами - параметри нецінової конкуренції. Вони виникають між товарами-замінниками та між їх виробниками, і виступають регулятором ціни. Нецінова конкуренція охоплює ті сфери, у яких цінова конкуренція потерпіла поразку [14].

Доцільним буде звернення до наукової праці Майкла Портера «Конкуренція» у якій він зазначив, що в будь-якій галузі, внутрішній чи міжнародній, такій, що виробляє товари чи послуги, правила конкуренції зводяться до дій п'яти конкурентних факторів, або ж сил:

- загроза появи продуктів-замінників;

- загроза появи нових гравців;

- ринкова влада постачальників;

- ринкова влада споживачів;

- рівень конкурентної боротьби [8].

Згідно з Й. Шумпетером, ефективна конкуренція можлива лише у випадках динамічної економіки, тобто там, де неперервний потік нововведень ламає стаціонарну ситуацію, яка є стрижнем конкуренції нового типу. Динамічну конкуренцію, що стимулюється прагненням отримання надприбутків завдяки перевагам у витратах та якості самого продукту, Й. Шумпетер назвав ефективною конкуренцією. Динамізацію ринкового процесу, як наслідок «нової конкуренції», він пов'язав з переходом до доби великого бізнесу (великих компаній, що концентрують у своїх руках значні ресурси, спроможні здійснювати довготривалі інвестиційні процеси тощо). Із нововведеннями асоціюється в концепції Й. Шумпетера і монополія нового типу.

Монопольний прибуток - це стимул та нагорода за нововведення, за Й. Шумпетером. Монополія, що є наслідком нововведень, ефективна, оскільки вона формується в умовах активної конкуренції. 3 нею несумісні застій, експлуатація покупців або постачальників через механізми цін [3].

Ініціатором «неокласичного синтезу» вважають П. Самуельсона, який об'єднав в одну концепцію неокласичну мікроекономіку й кейнсіанську макроекономіку. Він був одним із засновників неокейсіанства та запропонував теорію виявлених уподобань, у якій визначаються уподобання споживача на основі його поведінки. Учені П. Самуельсон та В. Нордхаус заперечують існування в сучасній економіці цілковито досконалої конкуренції, вказуючи на нереальність цього явища. На їхню 
думку, владу у світі мають іноді одна або декілька фірм, і переважно господарює недосконала конкуренція [1].

Конкурентна перевага - це ті характеристики, властивості товару або марки, які створюють для фірми певну перевагу над своїми прямими конкурентами. Ці характеристики (атрибути) можуть бути самими різними і відноситися як до самого товару (базової послуги), так і до додаткових послуг, які супроводжують базову до форм виробництва, збуту або продажу, специфічним для фірми або товару.

Зазначена перевага визначається в порівнянні з конкурентом, який займає найкращу позицію на ринку товару або в сегменті ринку. Цей найнебезпечніший конкурент називається пріоритетним [4].

У статті «Ера позиціонування» Джек Траут і Ель Рейс вводять поняття позиціонування. Конкурентне позиціонування - вибір, набуття (формування) конкурентної позиції фрірми та ознайомлення з нею свого конкурентного оточення [28].

Основою маркетингової стратегії нашого часу $є$ «конкурентне репозиціювання». Для отримання кращих позицій, необхідно репозиціонувати конкурентів, займаючи високі позиції в свідомості споживачів. Іншими словами, щоб переконати людей у новій ідеї продукту, необхідно витіснити стару ідею [12].

Ринковою конкуренцією називається боротьба фрірм за обмежений обсяг платоспроможного попиту споживачів, що ведеться фрірмами на доступних їм сегментах ринку [15].

Успішні підприємства - це ті, що швидко та ефективно розвиваються. Однак інноваційний бізнес не може розвиватися у вакуумі. Важливим $€$ вивчення ключових конкурентів компанії з економічної точки зору бізнесу:

- Який прихований веб-зв'язок між покупцями та постачальниками?

- Від кого вони залежать?

- Яка сутність та переваги цих відносин?

- Як їх порівняти з тим, що має компанія?

У літературі існує велика кількість визначень конкурентоспроможності, однак із тих, що є, найкраще підсумовує ті, які пристосовані до конкурентоспроможності фрірм. «Фірма $\epsilon$ конкурентоспроможною, якщо вона може виробляти продукцію та послуги вищої якості при нижчих витратах, ніж ї̈ внутрішні та міжнародні конкуренти. Конкурентоспроможність $\epsilon$ синонімом довгострокових прибутків фірми та її здатності компенсувати своїх співробітників та забезпечувати високу віддачу своїм власникам» [25].

Незважаючи на те, що вкрай важко визначити концептуальне міцне умовного визначення конкурентної переваги в літературі, Сіджалас X. та ін. створили умовне визначення, що включає всі приховані характеристики концепції конкурентної переваги і повністю відокремлює конкурентну перевагу від її джерел та від концепції вищої ефективності. Зокрема, Сіджалас X. зазначає, що конкурентна перевага - це «вищевказане середнє значення в галузі, яке виявляється у використанні ринкових можливостей та нейтралізації конкурентних загроз» [20].

У роботі Е. Піттса і М. Лагневика (1998) було прийнято, що «конкурентоспроможною галуззю $\epsilon$ така, яка має стійку здатність вигідно заробляти та підтримувати частку ринку на внутрішньому та/або зовнішньому ринках» [23].

Конкурентоспроможність - це економічна сила проти конкурентів на світовому ринку, де продукція, послуги, люди та інновації вільно рухаються, незважаючи на географічні межі [19].

М. Портер визначав конкурентоспроможність як порівняльну перевагу країни по відношенню до інших країн у світовій економіці, тобто здатність суб'єкта ринкових відносин бути на ринку на одному рівні з наявними там аналогічними конкуруючими суб'єктами [26].

Конкурентоспроможність країни є прямим відображенням її економічної привабливості в рамках прямих інвестицій, заснованих на міжнародній економіці та бізнесі. Існує велика кількість фракторів, які визначають конкурентоспроможність країни у світовому економічному зростанні та міжнародному бізнесі. Вони включають юридичні фрактори, природні ресурси, інституційні інвестиції, людський капітал, інфраструктуру, макроекономічні рамки, розмір ринку, первинну і медичну освіту, технологічний прогрес та динамічну економічну політику. Ці фрактори використовувались для того, щоб надати країнам та регіонам конкурентну перевагу, коли мова йде про світову економіку, але в цьому відношенні спостерігається зміна парадигми [29].

Успішні країни та регіони, такі як Індонезія, Сінгапур, Бразилія, Росія, Індія, Китай та Південна Афррика скоригували свої інвестиційні та економічні перспективи. Існують теорії, розроблені для пояснення змін конкурентоспроможності країн у контексті продуктивності та економічного лідерства [29].

Останнє визначення $€$ основною ідеєю світової частки ринку як міри конкурентоспроможності фірми. «Визначення конкурентоспроможності для нації повинно також бути пов'язане з ії здатністю генерувати ресурси, необхідні для задоволення її національних потреб» [18].

«Конкурентоспроможність» - це ідея, яку часто неправильно розуміють. «... конкурентоспроможність США визначають як ступінь, в якій фірми, що працюють в США, здатні успішно конкурувати в світовій економіці, підтримуючи високий рівень життя американців. Обидва аспекти цього визначення, міцний успіх та рівень життя $є$ визначальними. Якщо фірми в США стали 
більш здатними конкурувати в усьому світі через те, що зарплата та рівень життя в Америці знизилися, це було б ознакою того, що США як місце розташування бізнесу стали менш конкурентоспроможними» [24].

Єдиний спосіб, коли фрірми в США можуть виграти в усьому світі, підтримуючи високу заробітну плату, - це продуктивність - створення високої вартості товарів і послуг на одиницю розміщених людських, капітальних та природних ресурсів. Отже, конкурентоспроможність залежить від підвищення продуктивності праці в довгостроковій перспективі [24].

Ф. фон Хайєк стверджував, що «конкуренція $є$ процедурою відкриття, пізнання нового... саме за рахунок зростаючої конкуренції підвищується поступово наша ефективність... справа не лише в тому, що уся еволюція тримається на конкуренції, неперервна конкуренція необхідна навіть для забезпечення досягнутого» [13, с. 38-50].

Вчена Н. П. Тарнавська дає таке тлумачення фрункціонального підходу розуміння конкуренції: «Нині загальновизнаною є думка про переважаючу значущість функціонального підходу до розуміння сутності конкуренції. Наростання швидкості інноваційних процесів скорочення життєвого циклу продукції, індивідуалізація виробництва, загострює конкуренцію, і така ситуація обумовлює необхідність активізації наукових досліджень у сфері обґрунтування можливостей інноваційного розвитку підприємства» [11, с. 15].

Виходячи із різноманітності загальноприйнятих визначень категорії конкурентоспроможності, дослідники відзначають часовий (динамічний) і порівняльний характер цього показника:

- часовий характер (динамічність) означає, що досягнутий в окремий проміжок часу рівень конкурентоспроможності підприємства не може розглядатися як довгострокова характеристика його ринкової позиції незалежно від ефективності діяльності; протидія інших суб'єктів господарювання, рішучість та активність їх конкурентних стратегій можуть привести до втрати досягнутої позиції та зниження рівня конкурентоспроможності;

- порівняльний характер означає, що конкурентоспроможність не $є$ явищем, притаманним конкретному об'єкту; вона не випливає з його внутрішньої природи, а проявляється тільки за умов порівняння даного об'єкта з іншими; її можна оцінити порівнянням найбільш суттєвих показників діяльності підприємств; результатом цього порівняння є визначення рівня конкурентоспроможності [4].

У праці Гохберга О.Ю. конкурентоспроможність галузі пропонується розглядати як ступінь можливості галузі в умовах вільного ринку створювати блага, які відповідають вимогам як внутрішнього, так і зовнішніх ринків, при одночасному забезпеченні стабільного зростання та розвитку відповідного сектору економічної діяльності. Низка науковців вважають конкурентоспроможність галузі як ефективність роботи окремих галузей національного господарства, що оцінюється, окрім традиційних критеріїв, за показниками, що характеризують і описують міру живучості і динамічності галузі при різних варіантах розвитку економіки даної країни і всього світу в цілому [2].

Побережець Н. Б. зазначає у своїх працях такі особливості галузевої конкуренції:

- галузь втрачає всю конкурентоспроможність, якщо її частка знижується в загальному обсязі національного експорту або зростає загальний обсяг імпорту, дефльований на частку даного товару в загальному обсязі національного виробництва або споживання;

- галузь втрачає конкурентоспроможність, якщо ії частка знижується в загальному обсязі світового експерту або зростає частка світового імпорту, скоригована на частку країни у світовій торгівлі [7].

Конкурентоспроможність може бути визначена як здатність протистояти конкуренції та бути успішним у боротьбі з конкуренцією. Конкурентоспроможність буде тоді мати можливість продавати продукцію, яка відповідає вимогам попиту (ціна, якість, кількість) i, в той же час, забезпечити прибуток з часом, що дасть можливість фрірмі процвітати. Конкуренція може бути в межах внутрішніх ринків (у цьому випадку фірми або сектори в одній країні порівнюються між собою) або на міжнародному рівні (в цьому випадку проводяться порівняння між країнами) [22].

Існує також радикальна думка, яка стверджує, що термін «конкурентоспроможність», якщо правильно застосовувати, має не лише змістовне значення, але є явною частиною стратегії розвитку протягом усієї історії розвиненого світу. Це «школа конкурентоспроможності», що має «здатність до продажу» та «локальну привабливість». По великому рахунку, існує думка, що міжнародна конкурентоспроможність - це створення багатства в контексті міжнародних економічних взаємодій.

Визначення конкурентоспроможності можна описати, використовуючи концепцію «стійкої конкурентоспроможності», що ґрунтується на ідеї про те, що конкурентоспроможність сьогодні повинна бути досягнута без шкоди для можливості конкурентоспроможності завтра. Вона включає елементи якісного зростання, управління ресурсами, соціальної рівності, людського розвитку та добробуту. У цьому контексті поняття соціальної та екологічної стійкості пов'язані з концепцією конкурентоспроможності. Стійка конкурентоспроможність визначається як сукупність інститутів, політики та факторів, які роблять націю продуктивною в довгостроковій перспективі, забезпечуючи при цьому соціальну та екологічну стійкість. Соціальна стійкість визначається як інститути політики та фактори, які дозволяють усім членам суспільства відчути найкраще стабільність та безпеку, які 
максимально збільшують свій потенціал, щоб сприяти економічному процвітанню країни, в якій вони живуть. Екологічна стійкість визначається як інститути та фрактори, які забезпечують ефективне управління ресурсами для забезпечення процвітання сьогоднішнім та майбутнім поколінням [17].

Висновки 3 проведеного дослідження. Проаналізувавши основні теоретичні визначення конкуренції та конкурентоспроможності, провівши історичний екскурс з еволюції даних дефініцій, можна зробити узагальнення, що конкурентоспроможність - це економічна сила проти конкурентів на світовому ринку, де продукція, послуги, люди та інновації вільно рухаються, незважаючи на географрічні кордони. Крім економічних факторів, на конкурентоспроможність впливають такі соціальні інститути, як: державні органи влади, профспілки, фрінансові установи, соціально-політичні організації, власність, організаційні структури та ментальні звички, правила та кодекси поведінки. Отже, конкурентоспроможність тісно пов'язується з генетичним кодом нації.

\section{Література}

1. Александров І. О., Бурук Г.П. Еволюція дефініції конкурентоспроможності продукції. Маркетинг і менеджмент інновацій. 2010. № 2. С. 89-99.

2. Гохберг О. Ю. Конкурентоспроможність бізнесу: теоретико-методологічні основи аналізу. Вісник Львівської державної фрінансової академії. 2010. № 18. С. 50-56.

3. Злупко С. М. Історія економічної теорії: навчальний посібник. Київ : Знання, 2005. 719 с.

4. Ламбен Ж.-Ж. Стратегический маркетинг. Европейская перспектива / пер. с фрранц. СанктПетербург, 1996. 440 c.

5. Маркс К. Капитал : в 4 т. / пер. с нем. И. Степанова-Сковорода. Ленинград : 2-я типография «Печатный Двор» им. А.И. Горького. Главполиграфиздата при Совете Министров СССР. 1951. Т. 3. $932 \mathrm{c}$.

6. Маршалл А. Теория политической экономии. Принципы экономической науки : в 3-х т. / пер. с англ. Москва : Изд-во «Прогресс», 1993. Том 1. 432 с.

7. Побережець Н. Б. Оцінка конкурентоспроможності олійної галузі України на світовому ринку. Вісник Харківського НАУ ім. В. В. Докучаєва. Серія «Економіка АПК і природокористування». 2009. № 11. URL: http:/www.nbuv.gov.ua/portalChemBiol/Vkhnauekon/2009II/pdf//l43.pdf (дата звернення: 14.01.2020).

8. Портер М. Э. Конкуренция / пер. с англ. под ред. Я. В. Заболоцкого. Москва : Издательский дом «Вильямс», 2002. $496 \mathrm{c}$.

9. Про захист економічної конкуренції : Закон України від 11.01.2001 № 2210-III. URL: https://zakon.rada.gov.ua/laws/show/2210-14 (дата звернення: 14.01.2020).

10. Рикардо Д. Сочинения. Начала политической экономии и налогового обложения. Москва, 1955. Том I. 360 c.

11. Тарнавська Н. П. Управління конкурентоспроможністю підприємств: теорія, методологія, практика. Тернопіль : Економічна думка, 2008. 570 с.

12. Траут Джек, Райс Эл Позиционирование: битва за умы. Санкт-Петербург, 1981. 320 с.

13. Хайек Ф.А. Пагубная самонадеянность: Ошибки социализма / пер. с англ. под ред. У. У. Бартли. Москва : Новости, 1992. 302 с.

14. Чемберлин Э. Теория монополистической конкуренции. Москва : Экономика, 1996. 351 с.

15. Юданов А. Ю. Конкуренция: теория и практика : учебно-практ. пособие. 3-е изд. испр. и доп. Москва : ГНОМ и Д, 2001. 304 с. $478 \mathrm{c}$.

16. Ядгаров Я. С. История экономических учений : учебник для вузов. Москва : ИНФРА-М, 2001.

17. Andreoni V., Miola A. Competitiveness and Sustainable Development Goals 2016 / Publications Office 669 of the European Union, Luxembourg, 2016. URL: https://www.researchgate.net/publication/ 312211460_Competitiveness_and_Sustainable_Development_Goals (дата звернення: 15.01.2020).

18. Buckley P. J. Measures of International Competitiveness: A Critical Survey. Journal of Marketing Management. 1988. Vol. 4 (2). P. 175-200.

19. Chao-Hung W., Li-Chang H. The influence of dynamic capability on performance in the high technology industry: The moderating roles of governance and competitive posture. African Journal of Business Management. 2010. No. 4 (5). URL: https://www.researchgate.net/publication/ 268273528_The_influence_of_dynamic_capability_on_performance_in_the_high_technology_industry_The_ moderating_roles_of_governance_and_competitive_posture (дата звернення: 15.01.2020).

20. Christos Sigalas Competitive advantage: the known unknown concept. Management Decision. 2015. Vol. 53. P. 2004-2016. URL: https://www.researchgate.net/publication/ 283449416_Competitive_advantage_the_known_unknown_concept (дата звернення: 15.01.2020).

21. Explore the Cambridge Dictionary. URL: https://dictionary.cambridge.org/ spellcheck/english/?q=competetion (дата звернення: 15.01.2020).

22. Latruffe L. Competitiveness, Productivity and Efficiency in the Agricultural and Agri-Food Sectors. OECD : Paris, France, 2010. URL: https://www.oecd-ilibrary.org/docserver/5km91nkdt6d6- 
en.pdf?expires $=1581880154 \&$ id $=$ id\&accname $=$ guest $\&$ checksum $=72 \mathrm{C} 4 \mathrm{EC} 7 \mathrm{FF} 5 \mathrm{C} 10 \mathrm{~F} 26872 \mathrm{~B} 221 \mathrm{~A} 86 \mathrm{FE} 0 \mathrm{~F} 7 \mathrm{~F}$ (дата звернення: 15.01.2020).

23.Martin L., Westgren R., Durren van E. Agribusiness Competitiveness across National Boundaries. The American Journal of Agricultural Economics. December 1991. P. 1456-1464.

24. Michael E. Porter, Jan W. Rivkin Prosperity at Risk: Findings of Harvard Business School's Survey on U.S. Competitiveness. Harvard Business School, January 2012. URL: https://www.hbu.edu/competitiveness/Documents/hbscompsurvey.pdf (дата звернення: 15.01.2020).

25. Overseas Trade: Select Committee Report HL Deb. 03 December 1985. Vol. 468. URL: https://api.parliament.uk/historic-hansard/lords/1985/dec/03/overseas-trade-select-committee-report (дата звернення: 15.01.2020).

26. Porter M., Ketels C., Delgado M. The Microeconomic Foundations of Prosperity: Findings from the Business Competitiveness Index. In: WEF, The Global Competitiveness Report 2007-2008. WEF, Geneva, 2008. P. 51-96.

27. Sraffa P. The Laws of Returns under Competitive Conditions. Economic Journal. 1926. Vol. 36. P. 530-535.

28. Trout Jack. The Positioning Era Cometh. Advertising age features. 24.04.1972. P. 35-38.

29. Wanyamah Eric International Economics. URL: https://www.academia.edu/ 16820550/Competitiveness (дата звернення: 15.01.2020).

\section{References}

1. Aleksandrov, I.O. and Buruk, H.P. (2010), "The evolution of the definition of product competitiveness", Marketynh i menedzhment innovatsii, no. 2, pp. 89-99.

2. Hokhberh, O.Yu. (2010), "Business competitiveness: theoretical and methodological foundations of analysis", Visnyk Lvivskoi derzhavnoi finansovoi akademii, no. 18, pp. 50-56.

3. Zlupko, S.M. (2005), Istoriia ekonomichnoi teorii [History of economic theory], tutorial, Znannia, Kyiv, Ukraine, $719 p$.

4 Lamben, Zh.-Zh. (1996), Strategicheskiy marketing. Evropeyskaia perspektiva [Strategic marketing. European perspective], Saint-Petersburg, Russia, $440 \mathrm{p}$.

5. Marks, K. (1951), Kapital [Capital], Translated by I. Stepanova-Skovoroda, 2-ia tipografiia «Pechatnyy Dvor» im. A.I. Gorkogo, Leningrad, USSR, Vol. 3, 932 p.

6. Marshall, A. (1993), Teoriia politicheskoy ekonomii. Printsypy ekonomicheskoy nauki: $v$ 3-kh $t$. [The theory of political economy. Principles of economic science: in 3 Vol.], Izd-vo "Progress", Moscow, Russia, Vol. 1, 432 p.

7. Poberezhets, N.B. (2009), "Assessment of the competitiveness of Ukraine's oil industry in the world market", Visnyk Kharkivskoho NAU im. V. V. Dokuchaieva. Seriia "Ekonomika APK i pryrodokorystuvannia», no. 11, available at: http:/www.nbuv.gov.ua/portalChemBiol/Vkhnauekon/2009ll/pdf/ll43.pdf (access date January 14,2020$)$.

8. Porter, M.E. (2002), Konkurentsiia [Competition], Translated by Ya.V. Zabolotskiy, Izdatelskiy dom "Viliams", Moscow, Russia, $496 \mathrm{p}$.

9. The Verkhovna Rada of Ukraine (2001), Pro zakhyst ekonomichnoi konkurentsii [About protection of economic competition], Zakon Ukrainy dated 11.01.2001 no. 2210-III, available at: https://zakon.rada.gov.ua/laws/show/2210-14 (access date January 14, 2020).

10.Rikardo, D. (1955), Sochineniia. Nachala politicheskoy ekonomii i nalogovogo oblozheniia [Works. The beginnings of political economy and taxation], Moscow, Russia, Vol. I, 360 p.

11.Tarnavska, N.P. (2008), Upravlinnia konkurentospromozhnistiu pidpryiemstv: teoriia, metodolohiia, praktyka [Enterprise competitiveness management: theory, methodology, practice], Ekonomichna dumka, Ternopil, Ukraine, $570 \mathrm{p}$.

12.Traut, Dzhek and Rays, El (1981), Pozitsionirovanie: bitva za umy [Positioning: the battle for the minds], Saint-Petersburg, Russia, 320 p.

13.Khayek, F.A. (1992), Pagubnaia samonadeianost: Oshibki sotsializma [Pernicious Arrogance: The Mistakes of Socialism], Translated by U.U. Bartli, Novosti, Moscow, Russia, 302 p.

14.Chemberlin, E. (1996), Teoriia monopolisticheskoy konkurentsii [The theory of monopolistic competition], Ekonomika, Moscow, Russia, 351 p.

15.Yudanov, A.Yu. (2001), Konkurentsiia: teoriia i praktika [Competition: theory and practice], tutorial, 3 ed., GNOM i D, Moscow, Russia, 304 p.

16.Yadgarov, Ya.S. (2001), Istoriia ekonomicheskikh ucheniy [History of Economic Thought], highschool textbook, INFRA-M, Moscow, Russia, $478 \mathrm{p}$.

17.Andreoni, V. and Miola, A. (2016), Competitiviness and Sustainable Development Goals Publications Office 669 of the European Union, Luxembourg, available at: https://www.researchgate.net/publication/312211460_Competitiveness_and_Sustainable_Development_Goa Is (access date January 15, 2020). 
18.Buckley, P.J. (1988), "Measures of International Competitiveness: A Critical Survey", Journal of Marketing Management, Vol. 4 (2), pp. 175-200.

19.Chao-Hung, W. and Li-Chang, H. (2010), "The influence of dynamic capability on performance in the high technology industry: The moderating roles of governance and competitive posture", African Journal of Business Management, no. 4 (5), available at: https://www.researchgate.net/publication/ 268273528_The_influence_of_dynamic_capability_on_performance_in_the_high_technology_industry_The_ moderating_roles_of_governance_and_competitive_posture (access date January 15, 2020).

20.Christos, Sigalas (2015), "Competitive advantage: the known unknown concept", Management Decision, Vol. 53, pp. 2004-2016, available at: https://www.researchgate.net/publication/ 283449416_Competitive_advantage_the_known_unknown_concept (access date January 15, 2020).

21.Explore the Cambridge Dictionary, available at: https://dictionary.cambridge.org/ spellcheck/english/?q=competetion (access date January 15, 2020).

22.Latruffe, L. (2010), Competitiveness, Productivity and Efficiency in the Agricultural and Agri-Food Sectors, OECD, Paris, France, available at: https://www.oecd-ilibrary.org/docserver/5km91nkdt6d6en.pdf?expires $=1581880154 \&$ id $=$ id\&accname $=$ guest\&checksum $=72 \mathrm{C} 4 \mathrm{EC} 7 \mathrm{FF} 5 \mathrm{C} 10 \mathrm{~F} 26872 \mathrm{~B} 221 \mathrm{~A} 86 \mathrm{FE}$ FF7F (access date January 15, 2020).

23.Martin, L., Westgren, R., and van Durren, E. (1991), "Agribusiness Competitiveness across National Boundaries", The American Journal of Agricultural Economics, pp. 1456-1464.

24.Michael, E. Porter and Jan, W. Rivkin (2012), "Prosperity at Risk: Findings of Harvard Business School's Survey on U.S. Competitiveness," Harvard Business School, available at: https://www.hbu.edu/ competitiveness/Documents/hbscompsurvey.pdf (access date January 15, 2020).

25. Overseas Trade: Select Committee Report HL Deb, 03 December 1985, Vol. 468, available at: https://api.parliament.uk/historic-hansard/lords/1985/dec/03/overseas-trade-select-committee-report (access date January 15, 2020).

26.Porter, M., Ketels, C. and Delgado, M. (2008), "The Microeconomic Foundations of Prosperity: Findings from the Business Competitiveness Index", In: WEF, The Global Competitiveness Report 20072008 WEF, Geneva, Switzerland, pp. 51-96.

27.Sraffa, P. (1926), "The Lows of Returns under Competitive Conditions", Economic Journal, Vol. 36, pp. 50-535.

28.Trout, Jack (1972), "The Positioning Era Cometh", Advertising age features, pp. 35-38.

29.Wanyamah, Eric "International Economics", available

at:

https://www.academia.edu/16820550/Competitiveness (access date January 15, 2020).

Стаття надійшла до редакції 01.02.2020 p. 